\title{
Response of Crotalaria juncea to nickel exposure
}

\author{
Patrícia Felippe Cardoso $^{1}$, Priscila Lupino Gratão ${ }^{2}$, Rui Alberto Gomes-Junior ${ }^{2}$, Leonardo Oliveira Medici ${ }^{3}$ \\ and Ricardo Antunes Azevedo ${ }^{2 *}$
}

${ }^{1}$ Departamento de Genética e Evolução, Universidade Estadual de Campinas, CEP 13083-970, Campinas, SP, Brasil; ${ }^{2}$ Departamento de Genética, Escola Superior de Agricultura Luiz de Queiroz, Universidade de São Paulo, CEP 13418-900, Piracicaba, SP, Brasil; ${ }^{3}$ Departamento de Ciências Fisiológicas, Universidade Federal Rural do Rio de Janeiro, CEP 23890-000, Seropédica, RJ, Brasil. * Corresponding author:raazeved@esalq.usp.br

Received: 01/02/2005, Accepted: 02/04/2005

The response of Crotalaria juncea seedlings to nickel (Ni) was investigated. Ni was shown to accumulate mainly in the root system, with little being translocated to the shoots. Catalase (CAT) and glutathione reductase (GR) responses to Ni were also analyzed. CAT activity did not exhibit a clear trend in response to Ni exposure, whereas GR activity appeared to respond to the stress induced by Ni. The results suggest that in C. juncea GR participates in the detoxification of Ni-induced reactive oxygen species via the glutathione-ascorbate cycle.

Key words: antioxidant enzymes, heavy metals, nickel, reactive oxygen species.

Resposta de Crotalaria juncea à exposição ao níquel: A resposta de plântulas de Crotalaria juncea ao níquel (Ni) foi investigada. O Ni acumulou principalmente no sistema radicular, sendo pouco translocado para a parte aérea. As respostas da catalase (CAT) e da glutationa redutase (GR) também foram analisadas. A atividade de CAT não mostrou uma tendência clara em resposta à exposição ao $\mathrm{Ni}$, enquanto a atividade da GR pareceu responder ao estresse induzido pelo Ni. Os resultados sugerem que em $C$. juncea a GR participa da destoxificação das espécies ativas de oxigênio via ciclo glutationa-ascorbato.

Palavras-chave: enzimas antioxidantes, espécies reativas de oxigênio, metais pesados, níquel.

In the majority of natural environments the concentration of heavy metals in the soil is low and does not normally cause any significant phytotoxic effects (Gratão et al., 2005). The presence of some metals, like copper $(\mathrm{Cu})$, zinc $(\mathrm{Zn})$ and cadmium $(\mathrm{Cd})$ in soils are becoming a serious worldwide problem as a consequence of industrial activity, since the accumulation of these metals is able to cause significant reduction in crop yields (Wang et al., 2003). Nickel (Ni) has one essential role in plants, which is to form the active metallocenter of the hexameric enzyme urease (EC 3.5.1.5.) (Gerendas et al., 1999). Ni is not toxic at low concentrations, but it becomes toxic at high concentrations (Poulik, 1997). $\mathrm{Ni}$ is rapidly taken up by the plant root system and research with different plant species has shown that $\mathrm{Ni}$ is able to inhibit a large number of plant enzymes such as those of the Calvin cycle and chlorophyll biosynthesis (van Assche and Clijsters, 1990). Ni is also able to inhibit enzymes related to nitrogen metabolism (Boussama et al., 1999) and sulphate assimilation (Lee and Leustek, 1999).

Exposure to heavy metals and other adverse environmental factors can disrupt cellular homeostasis and enhance the production of several activated oxygen species, designated as reactive oxygen species (ROS), such as superoxide $\left(\mathrm{O}_{2}^{\bullet-}\right)$, hydroxyl radicals $\left({ }^{\bullet} \mathrm{OH}\right)$, oxygen singlet $\left(\mathrm{O}_{2}{ }^{1}\right)$ and hydrogen peroxide $\left(\mathrm{H}_{2} \mathrm{O}_{2}\right)$, that are produced continuously by plant metabolism (Foyer and Noctor, 2003). Plants possess very efficient enzymatic and non-enzymatic antioxidant defense systems that allow the scavenging of ROS and protection of plant cells from oxidative damage (Gratão et al., 2005). $\mathrm{H}_{2} \mathrm{O}_{2}$ can be directly metabolized by peroxidases, particularly those from the cell wall and by CAT in the peroxissome (Azevedo et al., 1998). In the chloroplast, $\mathrm{O}_{2}{ }^{-}$is converted by SOD into $\mathrm{H}_{2} \mathrm{O}_{2}$, which is then detoxified to $\mathrm{H}_{2} \mathrm{O}$ and $\mathrm{O}_{2}$ by the glutathione-ascorbate cycle, which 
involves the action of several enzymes, including GR (Foyer et al., 2003). Several studies have been carried out with plants to evaluate the effect of heavy metals on the activity of antioxidant enzymes such as SOD, CAT and GR (Gratão et al., 2005). The present study was carried out to examine the effects of $\mathrm{Ni}$ on the activity of two antioxidant enzymes in the legume plant species $C$. juncea, commonly used as a compost (green fertilizer).

Seeds of $C$. juncea were germinated on moistened germinating paper in a growth chamber under controlled environmental conditions $\left(60-80 \%\right.$ relative humidity, $27-30^{\circ} \mathrm{C}$ temperature and a $16 / 8 \mathrm{~h}$ photoperiod at $350 \mu \mathrm{mol} \cdot \mathrm{m}^{-2} \cdot \mathrm{s}^{-1}$ irradiance) for $7 \mathrm{~d}$. At the end of this period, seedlings of approximately the same size were selected and transferred to $1.7 \mathrm{~L}$ pots containing Hoagland's nutrient solution and maintained in a hydroponic system in a glasshouse $(16 / 8 \mathrm{~h}$ photoperiod at $25-32^{\circ} \mathrm{C}$ ). After a further $7 \mathrm{~d}$ growth under these conditions, the Hoagland solution was replaced with a new solution containing different $\mathrm{NiCl}_{2}$ concentrations $(0$ mmol.L $\mathrm{L}^{-1}, 0.05 \mathrm{mmol} . \mathrm{L}^{-1}$ and $\left.0.5 \mathrm{mmol} . \mathrm{L}^{-1}\right)$. After periods of $12,24,48,72$ and $96 \mathrm{~h}$ of growth in the presence of $\mathrm{Ni}$, seedlings were collected, washed in distilled-deionized water and stored frozen at $-80^{\circ} \mathrm{C}$ for further analysis. The experimental design was a randomized complete block with treatments arranged as individual pots, with ten plants per plot, each replicated 3 times.

$\mathrm{Ni}$ accumulation in root and shoot samples taken from seedlings of $C$. juncea exposed to $0 \mathrm{mmol}^{-1}$ and 0.5 mmol.L $\mathrm{L}^{-1} \mathrm{NiCl}_{2}$ was determined using the energy disperse $\mathrm{X}$-Ray fluorescence method with the radioisotopic excitation technique carried out at the Center for Nuclear Energy in Agriculture, CENA/USP as described by Nascimento Filho (1999). Enzyme extraction of roots and shoots of C. juncea seedlings was carried out according to Pereira et al. (2002). Protein concentration for all samples was determined by the method of Bradford (1976) using bovine serum albumin as standard. CAT and GR activities were determined as described by Medici et al. (2004). Lipid peroxidation in $C$. juncea shoots was determined by estimating the malondialdehyde (MDA) content following the method of Heath and Packer (1968). The concentration of MDA was calculated using an extinction coefficient of $155 \mathrm{mM}^{-1} . \mathrm{cm}^{-1}$.

Using X-ray absorption spectroscopy we determined the accumulation of $\mathrm{Ni}$ in roots and shoots of $C$. juncea after growth in $0.5 \mathrm{mmol} . \mathrm{L}^{-1}$ for a period of up to $96 \mathrm{~h}$ (figure 1). It was observed that $\mathrm{Ni}$ entered the roots very rapidly with approximately $100 \%$ of the Ni being taken up within

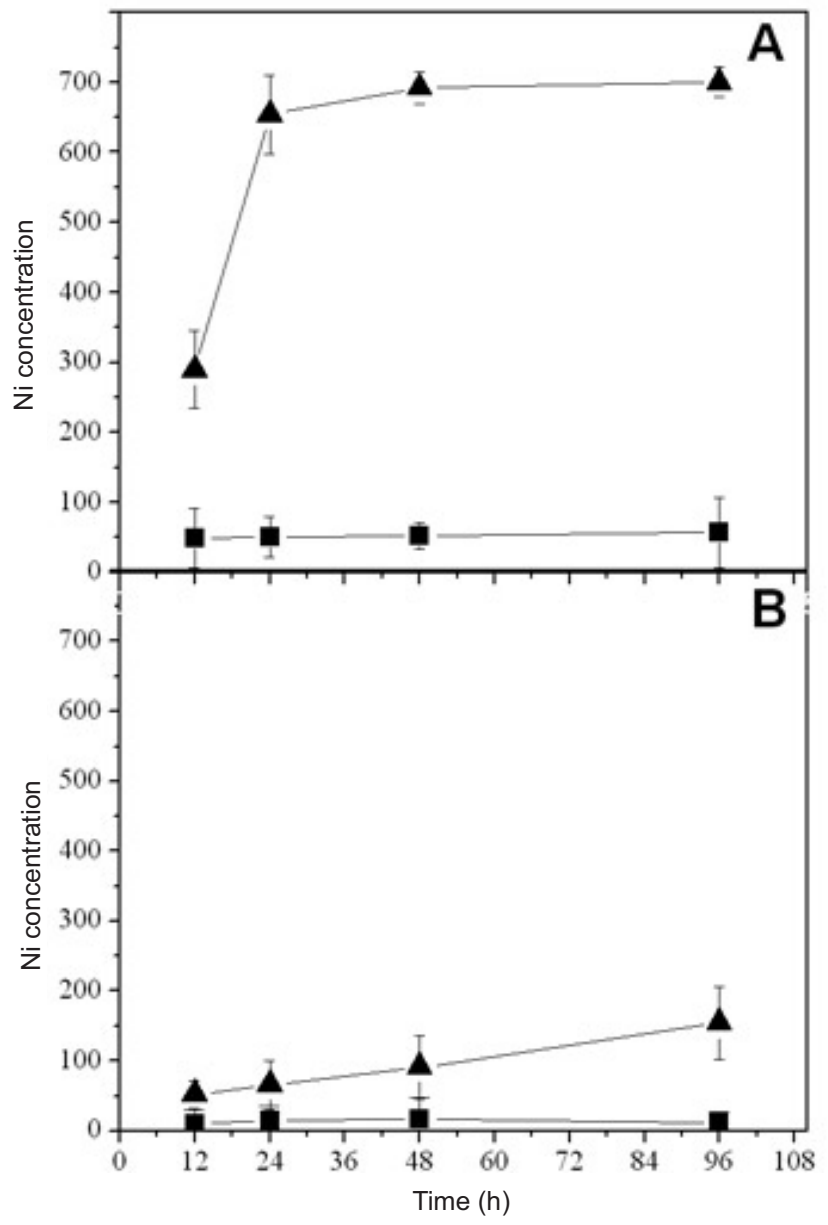

Figure 1. Ni accumulation (ppm) in C. juncea seedlings. Ni accumulation was determined in the roots (A) and shoots (B) of seedlings grown over a $96 \mathrm{~h}$ period. Control zero $\mathrm{NiCl}_{2}(\boldsymbol{\square})$ and $0.5 \mathrm{mmol} . \mathrm{L}^{-1} \mathrm{NiCl}_{2}(\mathbf{\Delta})$.

the first $24 \mathrm{~h}$ of growth in the presence of the metal (figure 1A). However, little was translocated to the upper parts of the plants (figure 1B). In an earlier report, the accumulation of Ni in Trigonella corniculata tissues was shown to increase consistently with increasing $\mathrm{Ni}$ concentrations applied to the roots, with the metal accumulating in much higher amounts in the roots compared to the shoots (Parida et al., 2003). Similar behavior has been reported for the heavy metal $\mathrm{Cd}$, which can also accumulate rapidly and preferentially in the roots, with little being translocated to the other parts of the plant (Vitória et al., 2001; Pereira et al., 2002). Furthermore, among the several distinct proposed mechanisms for heavy metal tolerance, in the case of Alyssum bertolonii hairy roots, the tolerance to Ni appears to be related to the ability to withstand the effects of plasma membrane depolarisation (Boominathan and Doran, 2002). In addition, Prasad and Freitas (2000) have stated that different parts of plants have different 
adsorption abilities due to localization of specific ligands that have affinity to bind to a particular metal. Wang et al. (2003) studying rice plants which were grown to maturity in paddy soils contaminated with heavy metals observed that the metals could be translocated to the rice grain, with the total metal content being highly concentrated in the rice biomass. This does not appear to be the case of $\mathrm{Ni}$ in C. juncea.

Previous studies have stated that $\mathrm{Ni}$ cannot generate ROS directly, however, this metal could indirectly trigger oxidative stress by reactivation of proteins, including antioxidant enzymes (Boominathan and Doran, 2002). Biochemical analyses of CAT and GR enzymes were carried out in roots and shoots of $C$. juncea exposed to different $\mathrm{NiCl}_{2}$ concentrations $\left(0 \mathrm{mmol} . \mathrm{L}^{-1}, 0.05 \mathrm{mmol} . \mathrm{L}^{-1}\right.$ and 0.5 mmol. $\left.\mathrm{L}^{-1}\right)$ in order to investigate the possible induction of these enzymes by $\mathrm{Ni}$, which may imply their involvement in the metal tolerance mechanism of this plant species. The choice of these two enzymes was also based on their responses to Cd stress in C. juncea (Pereira et al., 2002).

CAT activity in the roots did not exhibit any major variation in both $0.05 \mathrm{mmol} . \mathrm{L}^{-1}$ and $0.5 \mathrm{mmol} . \mathrm{L}^{-1} \mathrm{NiCl}_{2}$ treatments over the duration of the experiment (figure $2 \mathrm{~A}$ ).
A similar result was observed in the shoots (figure 2B). However, CAT activity in the control treatment varied differently in both tissues, exhibiting a reduction in roots after $48 \mathrm{~h}$ of treatment (figure 2A), contrasting the shoots where an increase in activity was observed after $24 \mathrm{~h}$ (figure 2B). With regard to the $\mathrm{NiCl}_{2}$ treatments, CAT activity did not exhibit a clear trend in any of the tissues, but varied during the time span of the experiment (figures $2 \mathrm{~A}$ and $2 \mathrm{~B}$ ). The major function of CAT in leaves is to metabolize the $\mathrm{H}_{2} \mathrm{O}_{2}$ liberated in the peroxisomes during photorespiration following the conversion of glycollate to glyoxylate (Azevedo et al., 1998). Another class of CAT is located in vascular tissues and may be also involved in the protection against environmental stress (Willekens et al., 1995). Apart from the variation in levels of CAT activity observed between 24 and $72 \mathrm{~h}$ of Ni treatment, when a drastic increase in activity was observed in the shoots, the results cannot support a primary response of CAT to Ni-induced oxidative stress with ROS generation, although an increased CAT activity in response to Ni treatment might be circumstantial evidence to support the hypothesis that Ni could cause the formation of ROS. Furthermore, evidence for a signalling mechanism from
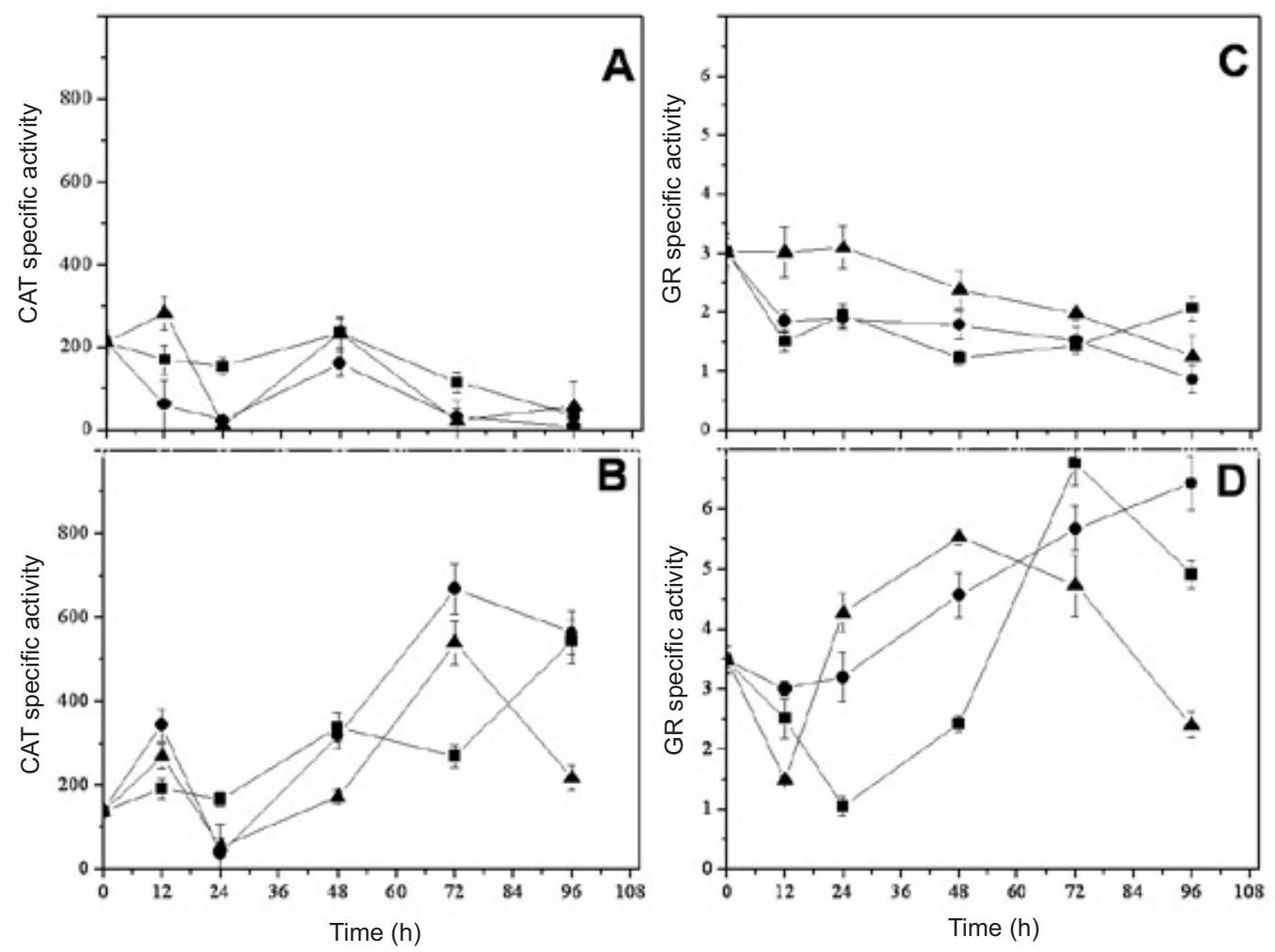

Figure 2. CAT specific activity ( $\mu \mathrm{mol} \cdot \mathrm{min}^{-1} \cdot \mathrm{mg}^{-1}$ protein) in the roots (A) and shoots (B) and GR activity $\left(\mu \mathrm{mol} \cdot \mathrm{min}^{-1} \cdot \mathrm{mg}^{-1}\right.$ protein) in the roots $(\mathrm{C})$ and shoots (D) of $C$. juncea seedlings grown over a $96 \mathrm{~h}$ period. Control zero $\mathrm{NiCl}_{2}(\boldsymbol{\square}), 0.05$ mmol.L $\mathrm{LiCl}_{2}(\bullet)$ and $0.5 \mathrm{mmol} \cdot \mathrm{L}^{-1} \mathrm{NiCl}_{2}(\mathbf{\Delta})$. 
roots to shoots in relation to CAT activity responding to a $\mathrm{Ni}$-induced oxidative stress cannot be supported based on our results in $C$. juncea. On the other hand, the sharp increase in CAT activity in shoots of seedlings of $C$. juncea support the hypothesis that $\mathrm{Ni}$ may induce the production of $\mathrm{H}_{2} \mathrm{O}_{2}$ in the peroxisome, which is then metabolized by CAT. The lack of any major significant alteration in CAT activity in the roots of $C$. juncea following treatment with $\mathrm{NiCl}_{2}$ is similar to the results reported for the roots of this plant species when treated with $\mathrm{CdCl}_{2}$ (Pereira et al., 2002). The response of CAT activity to $\mathrm{Al}$ has also been shown to be dependent on the plant species and tissues analyzed (Cakmak and Horst, 1991). In another study, the activity of CAT in young wheat leaves was impaired by an increase in Cr supply (Milone et al., 2003). A similar study in maize showed that there was an evident increase in CAT activity in response to $\mathrm{Ni}$ treatment (Baccouch et al., 2001).

GR can be located in the chloroplasts, cytoplasm and mitochondria of higher plants and is involved in the breakdown of $\mathrm{H}_{2} \mathrm{O}_{2}$ via the ascorbate-glutathione cycle (Azevedo et. al., 1998). In this study, the activity of GR was determined in roots and shoots of $C$. juncea seedlings treated with $\mathrm{NiCl}_{2}$. Contrary to $\mathrm{CAT}$, interesting changes in GR activity were observed in response to the Ni-induced stress in $C$. juncea seedlings (figures $2 \mathrm{C}$ and 2D), particularly in the shoots. In roots, GR activity was drastically reduced in the control plants during the first $24 \mathrm{~h}$ of growth, but did not vary afterwards (figure $2 \mathrm{C}$ ). In an almost identical manner, GR activity in the $0.05 \mathrm{mmol} . \mathrm{L}^{-1} \mathrm{NiCl}_{2}$ treatment was also drastically reduced after $12 \mathrm{~h}$ of treatment but remained essentially unaltered afterwards (figure 2C). For the 0.5 mmol.L $\mathrm{L}^{-1} \mathrm{NiCl}_{2}$ concentration, a reduction in GR activity was also observed, however, the decrease in activity was much slower than that observed for the control and $0.05 \mathrm{mmol.L}$ ${ }^{1} \mathrm{NiCl}_{2}$ treatments. The results suggest that the higher $\mathrm{Ni}$ concentration tested has probably induced oxidative stress and ROS generation, since the slower fall in GR activity over the duration of the treatment probably was important in maintaining the glutathione-ascorbate cycle operating in order to detoxify the ROS induced by the exposure of the roots to $\mathrm{Ni}$.

GR activity in the shoots was dramatically affected by both Ni concentrations tested (figure 2D). As in roots, GR activity in the control exhibited a dramatic initial reduction up to $24 \mathrm{~h}$ of treatment, followed by a sharp 6-fold increase up to $72 \mathrm{~h}$ of treatment, after which there was a slight reduction over the next $24 \mathrm{~h}$ of treatment. Curiously, both
Ni concentrations exhibited identical behaviors, but with different delays. The $0.05 \mathrm{mmol} . \mathrm{L}^{-1} \mathrm{NiCl}_{2}$ treatment did not result in a sharp drop in GR activity, but induced a slight continuous increase, whereas the 0.5 mmol.L-1 $\mathrm{NiCl}_{2}$ treatment exhibited a more significant reduction in GR activity rapidly followed by a sharp increase and then a drop in GR activity up to $96 \mathrm{~h}$ in a similar manner to the control treatments. The result clearly indicates that GR activity responds more effectively to Ni-induced oxidative stress than CAT. As already mentioned, although GR activity is reduced in the roots, the highest $\mathrm{Ni}$ concentration tested indicates that GR activity appears to be detoxifying Ni-induced ROS, whereas the oxidative stress appears to be more pronounced in the upper parts of the plant, since with the increase in $\mathrm{Ni}$ concentration, the GR activity responses were faster when compared to the natural variation of the control GR activity (figures $2 \mathrm{C}$ and 2D).

The majority of studies determining the response of GR to metal exposure have shown that GR activity increases as part of the defense against the metal-induced stress, an alteration which has often been metal dose dependent and variable over time (Gratão et al., 2005). GSH is considered essential in plant cells, although some plants contain tripeptide homologs of GSH, in which the carboxy terminal glycine is replaced by other amino acids, such as homoglutathione ( $\gamma$-glutamylcysteinylalanine), hydroxymethylglutathione $(\gamma$ glutamylcysteinylserine), that may partly or totally replace GSH. Another GSH homologue, $\gamma$-glutamylcysteinylglut amate, was discovered in maize seedlings exposed to $\mathrm{Cd}$ (Prasad, 1997). The oxidized forms of GSH homologues can be reduced by yeast GR, suggesting similar physiological and biochemical roles for the more widespread GSH (Foyer and Noctor, 2003). Such a result suggests that this enzyme is responding to metal stress by maintaining glutathione in the reduced form prior to incorporation into phytochelatins (PCs), and/or via the activation of the ascorbate-glutathione cycle for the removal of $\mathrm{H}_{2} \mathrm{O}_{2}$ (Gratão et al., 2005). This information also appears to be valid for CAT and other antioxidant enzymes, since the responses vary according to the metal, plant species, concentration of the metal and even plant tissues. The data obtained here suggest that Ni appears to be inducing ROS production, however, the ROS produced may be metabolized by other antioxidant enzymes, which were not tested in this study, or the production of ROS is not significantly high. For instance, C. juncea plants submitted to Cd exposure exhibited a 6-fold increase in GR activity in the leaves when compared to the untreated control (Pereira et al., 
2002), clearly indicating a role for GR in the detoxification of Cd-induced ROS via the glutathione-ascorbate cycle. In any case, further studies are necessary and should concentrate on analyzing other antioxidant enzymes and ROS production.

Lipid peroxidation is associated with oxidative stress and contributes to the breakdown of the functional and structural integrity of biological membranes, resulting in increases in the permeability of the plasma membrane, which leads to leakage of $\mathrm{K}^{+}$ions and other solutes, amino acids oxidation and eventually may cause cell death (Gratão et al., 2005). ROS can react with unsaturated fatty acids to cause peroxidation of essential lipids in the membranes of intracellular organelles. Moreover, $\mathrm{H}_{2} \mathrm{O}_{2}$ can accumulate in plant tissues where the antioxidant activities are suppressed (Scandalios, 2005). MDA is one of several low molecular weight end products formed via decomposition of certain primary and secondary lipid peroxidation products (Liu et al., 1997). Pandolfin et al. (1996) suggested that $\mathrm{Ni}$ induces lipid peroxidation, degrading membrane lipids and causing conformational changes in membrane proteins. In this study, lipid peroxidation was monitored by measuring the concentration of MDA in shoots of control and $0.5 \mathrm{mmol} . \mathrm{L}^{-1} \mathrm{NiCl}_{2}$ treated seedlings. The degree of lipid peroxidation varied very little in shoots of control plants, however, a steady almost linear increase in MDA was observed for the Ni treatment, clearly indicating a Ni-induced oxidative stress in C. juncea seedling shoots (figure 3). Such a result is in agreement with data obtained by Baccouch et al. (2001) who showed that Ni oxidative disorder is part of the overall expression of $\mathrm{Ni}$ toxicity in roots of maize with enhanced lipid peroxidation.

In this study, the growth of $C$. juncea roots was essentially very little affected by $\mathrm{Ni}$, however, the physiological parameters analyzed to investigate oxidative stress indicated that ROS are being produced, leading to lipid peroxidation in the shoots. Based on the data obtained for CAT and GR activities, it is possible to suggest that the glutathioneascorbate cycle is more active under Ni stress, also causing an increase in lipid peroxidation. Future studies should concentrate on a detailed investigation of other enzymatic systems and non-enzymatic systems. The only previous report for $C$. juncea in relation to heavy metal induced oxidative stress was carried out with $\mathrm{Cd}$, where a clearer response was obtained, indicating that GR may be involved in the main line of antioxidative defense in this plant species when Cd-induced oxidative stress is concerned (Pereira et al., 2002). In both studies, C. juncea exhibited a more tolerant response to both metals, suggesting that this species should also be investigated and tested in phytoremediation.

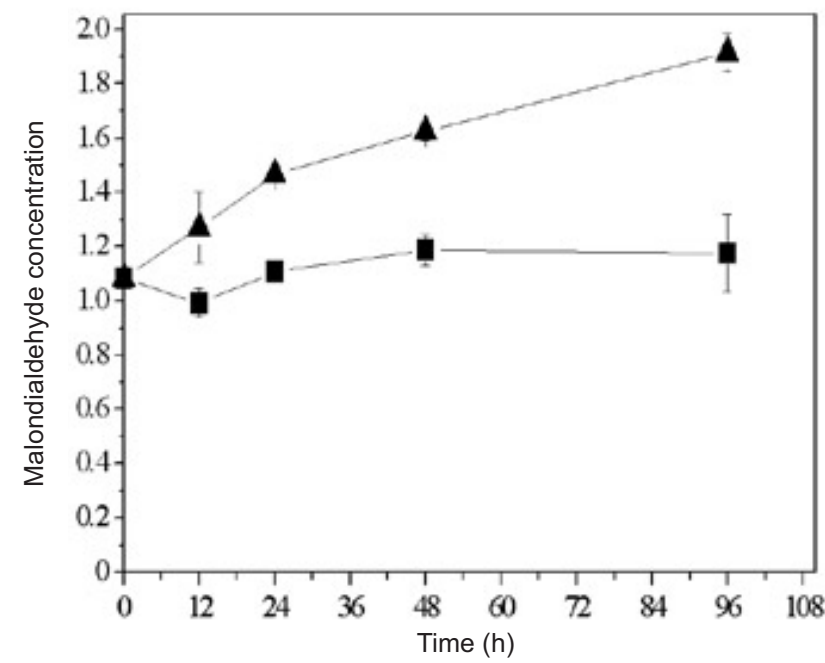

Figure 3. Malonaldialdehyde (MDA) concentrations ( $\mu \mathrm{mol} . \mathrm{g}^{-1}$ fresh weight) in the shoots of seedlings grown over a $96 \mathrm{~h}$ period. Control zero $\mathrm{NiCl}_{2}(\boldsymbol{\square})$ and 0.5 mmol.L-1 $\mathrm{NiCl}_{2}(\boldsymbol{\Delta})$.

\section{REFERENCES}

Azevedo RA, Alas RM, Smith PJ, Lea PJ (1998) Response of antioxidant enzymes to transfer from elevated carbon dioxide to air and ozone fumigation, in the leaves and roots of wild-type and a catalase-deficient mutant of barley. Physiol. Plant. 104:280-292.

Baccouch S, Chaoui El, Ferjani E (2001) Nickel-induced oxidative damage in Zea mays shoots. J. Plant. Nutr. 7:10851097.

Boominathan R, Doran PM (2002) Ni-induced oxidative stress in roots of the Ni hyperaccumulator Alyssum bertolonii. New Phytol. 156:205-215.

Boussama N, Quariti O, Ghorbal MH (1999) Changes in growth and nitrogen assimilation in barley seedlings under cadmium stress. J. Plant. Nutr. 22:731-752.

Bradford MM (1976) Rapid and sensitive method for the quantitation of microgram quantities of protein utilizing the principle of protein-dye binding. Anal. Biochem. 72:248-254.

Cakmak I, Horst WJ (1991) Effect of aluminum on lipid-peroxidation, superoxide-dismutase, catalase and peroxidaseactivities in root-tips of soybean (Glycine max). Physiol. Plant. 83:463-468.

Foyer CH, Noctor G (2003) Redox sensing and signalling associated with reactive oxygen in chloroplasts, peroxisomes and mitochondria. Physiol. Plant. 119:355-364.

Gerendas J, Polacco JC, Freyermuth SK, Sattelmacher B (1999) Significance of nickel for plant growth and metabolism. J. Plant. Nutr. Soil Sci. 162:241-256.

Gratão PL, Polle A, Lea PJ, Azevedo RA (2005) Making the life of heavy metal-stressed plants a little easier. Funct. Plant Biol. 32:481-494.

Heath RL, Packer L (1968) Photoperoxidation in isolated chloroplast. I. Kinetics and stoichiometry of fatty acid peroxidation. Arch. Biochem. Biophys. 125:2141-2145. 
Lee SM, Leustek T (1999) The effect of cadmium on sulphate assimilation enzymes in Brassica juncea. Plant. Sci. 141:201-207.

Liu J, Yeo HC, Doniger SJ, Ames BN (1997) Heavy metal separation by functionalized mesoporous materials. Abstr. Pap. Am. Chem. S. 214:90-91.

Medici LO, Azevedo RA, Smith RJ, Lea PJ (2004) The influence of nitrogen supply on antioxidant enzymes in plant roots. Funct. Plant Biol. 31:1-9.

Milone MT, Sgherri C, Clijster H, Navari-Izzo F (2003) Antioxidant responses of wheat treatment with realistic concentration of cadmium. Environ. Exp. Bot. 50:265-276.

Nascimento Filho V (1999) Técnicas Analíticas nucleares de fluorescência de raios $X$ por dispersão de energia (EDXRF) e por reflexão total (TXRF), 32p., Piracicaba, ESALQ-USP.

Pandolfin T, Gabbrielli R, Ciscato N (1996) Nickel toxicity in two durum wheat cultivars differing in drought sensitivity. J. Plant. Nutr. 19:1611-1627.

Parida BK, Chhibba IM, Nayyar VK (2003) Influence of nickel-contaminated soils on fenugreek (Trigonella corniculata L.) growth and mineral composition. Sci. Hortic. 98:113-119.
Pereira GJG, Molina SMG, Lea PJ, Azevedo RA (2002) Activity of antioxidant enzymes in response to cadmium in C. juncea. Plant Soil 239:123-132.

Poulik Z (1997) The danger of accumulation of nickel in cereals on contaminated soil. Agric. Ecosyst. Environ. 63:25-29.

Prasad MNV, Freitas H (2000) Removal of toxic metals from solution by leaf, stem and root phytomass of Quercus ilex L. (holly oak). Environ. Pollut. 110:277-283.

Prasad MNV (1997) Plant Ecophysiology. J. Wiley and Sons, NY.

Scandalios JG (2005) Oxidative stress: molecular perception and transduction of signal triggering antioxidant gene defenses. Braz. J. Med. Biol. Res. 38:995-1014.

Van Assche F, Clijsters H (1990) Effects of metals on enzyme activity in plants. Plant Cell Environ. 13:195-206.

Vitória AP, Lea PJ, Azevedo RA (2001) Antioxidant enzymes responses to cadmium in radish tissue. Phytochemistry 57: 701-710.

Wang QR, Cui YS, Liu XM, Dong YT, Christie P (2003) Soil contamination and plant uptake of heavy metals at polluted sites in China. J. Environ. Sci. Heal. A. 38:823-838.

Willekens H, Inzé D, Van Montagu M, Van Camp W (1995) Catalases in plants. Mol. Breeding 1:207-228. 